\title{
Selective feeding behaviour of key free-living protists: avenues for continued study
}

\author{
David J. S. Montagnes ${ }^{1, *}$, Ana B. Barbosa ${ }^{2}$, Jens Boenigk ${ }^{3}$, Keith Davidson ${ }^{4}$, \\ Klaus Jürgens ${ }^{5}$, Miroslav Macek ${ }^{6,9}{ }^{\text {, Jacqueline D. Parry }}{ }^{7}$, Emily C. Roberts ${ }^{8}$, \\ Karel Šimek ${ }^{9}$
}

\footnotetext{
${ }^{1}$ School of Biological Sciences, Biosciences Building, University of Liverpool, Crown Street, Liverpool L69 7ZB, UK ${ }^{2}$ CIMA, Center for Marine and Environmental Research, Universidade do Algarve, Campus de Gambelas, 8005-139 Faro, Portugal

${ }^{3}$ Institute for Limnology, Austrian Academy of Sciences, Mondseestr. 9, 5310 Mondsee, Austria

${ }^{4}$ Scottish Association for Marine Science, Dunstaffnage Marine Laboratory, Oban, Argyll PA37 1QA, UK

${ }^{5}$ Leibniz Institute for Baltic Sea Research, Department of Biological Oceanography, Seest. 15, 18119 Rostock-Warnemünde, Germany

${ }^{6}$ National Autonomous University of Mexico, FES Iztacala, Department of Tropical Limnology, Av. de los Barrios 1, 54090 Tlalnepantla, Edo. México, Mexico

${ }^{7}$ Division of Biomedical and Life Sciences, School of Health and Medicine, Lancaster University, Lancaster LA1 4YQ, UK

${ }^{8}$ Biological Sciences, Swansea University, Singleton Park, Swansea SA2 8PP, UK

${ }^{9}$ Biology Centre of the Academy of Sciences of the Czech Republic, v.v.i., Institute of Hydrobiology, Na Sádkách 7, 37005 České Budéjovice, Czech Republic
}

\begin{abstract}
Phagotrophic protists are diverse and abundant in aquatic and terrestrial environments, making them fundamental to the transfer of matter/energy within their respective food webs. Recognising their grazing impact is essential to evaluate the role of protists in ecosystems, and this includes appreciating prey selectivity. Efforts have been made by groups and individuals to understand selective grazing behaviour by protists: many approaches and perspectives have been pursued, not all of which are compatible. This article, which is not a review, is the product of our discourse on this subject at the SAME 10 meeting. It is the work of individuals, assembled for their breadth of backgrounds, approaches, views, and expertise. Firstly, to communicate ideas and approaches, we develop a framework for selective feeding processes and suggest 6 steps: searching, contact, capture, processing, ingestion, digestion. We then separate study approaches into 2 categories: (1) those examining whole organisms at the community, population, and individual levels, and (2) those examining physiology and molecular attributes. Finally, we explore general problems associated with the field of protistan selective feeding (e.g. linking food selection into food webs and modeling). We do not present all views on any one topic, nor do we cover all topics; instead, we offer opinions and suggest avenues for continued study. Overall, this paper should stimulate further discourse on the subject and provide a roadmap for the future.
\end{abstract}

KEY WORDS: Amoeba · Ciliate · Flagellate · Grazing · Ingestion · Phagotrophic · Protozoa Resale or republication not permitted without written consent of the publisher

\section{INTRODUCTION}

For the purpose of this dicourse, we operationally consider all unicellular eukaryotes that ingest (phagocytise) organic matter as part or all of their source of energy as 'phagotrophic protists'. In particular, we focus on key non-parasitic (i.e. free-living) taxa, with an emphasis on species that are not strictly associated with substrates and are mainly pelagic, although some of our insights may be transferable to other lifestyles. The phagotrophic protists include a wide range of taxa generally within the size range of 2 to $200 \mu \mathrm{m}$; 
however, some amoeboid forms such as radiolaria and foraminifera can attain diameters of up to $25 \mathrm{~cm}$ (e.g. DeLaca et al. 2002, Laureillard et al. 2004). Phagotrophic protists include strictly heterotrophic taxa as well as mixotrophic taxa that combine phagotrophy and phototrophy by sequestering plastids derived from their prey (kleptoplastidy) or by harbouring complete algal endosymbionts (see Stoecker 1998). The great abundance of phagotrophic protists in aquatic environments, whether it be in soil interstices, groundwaters, biofilms, ponds, lakes, the open ocean, or a myriad of other aquatic ecotones, makes them fundamental to the transfer of matter and energy within their respective food webs. These eukaryotic microbes exhibit a variety of feeding strategies. This allows them to ingest a wide range of prey types, such as phytoplankton, bacteria, and other heterotrophs, including protists, whole metazoa, and their products (Sherr \& Sherr 1997, Hansen \& Calado 1999). Recognising the grazing impact of such protists is, therefore, essential for the evaluation of their contribution to ecosystem processes, and this clearly includes appreciating prey selectivity.

Over the last few decades there has been a concerted effort by many individuals and groups to understand the selective grazing behaviour of protists. Inevitably, many approaches and perspectives have been pursued, not all of which have been compatible. Fortunately, and appropriately, events such as the 10th Symposium on Aquatic Microbial Ecology (SAME 10) provide a mechanism for discourse and the synthesis of approaches, both practical and conceptual. This article, which we expressly state is not a review, is the successful product of such a discourse. It is the work of individuals, specifically assembled for their breadth of backgrounds, approaches, views, and expertise. We do not present all possible views on any one topic, nor do we cover all topics associated with selective feeding. However, we do offer opinions on several related topics and show avenues that we consider, at present, to provide sensible future directions of study on this key subject.

We have included key or appropriate references for each topic. Hence, while our list of citations may occasionally appear unbalanced, our referencing is specifically designed to place focus on those poorly studied areas that we consider important. The initiated reader will recognise the great wealth of literature on these subjects and will hopefully excuse our omissions. The uninitiated reader is encouraged to pursue the topics below, using this synthesis as a node in the vast web of knowledge on the subject. In contrast to an exhaustive survey, we have attempted to place our ideas into a conceptual framework of protist feeding (Fig. 1). We anticipate that this will provide focus for future work to be conducted by ourselves and others.

\section{BACKGROUND AND DIRECTION}

It is now well established that prey populations can be strongly influenced by protistan grazers. Protists can control or influence distinct attributes of prey populations, ranging from the size of the prey standing stock to its taxonomic composition and to the morphology and activity of prey (Hahn \& Höfle 2001, Jakobsen \& Tang 2002, Jürgens \& Matz 2002, Sherr \& Sherr 2002, Pernthaler 2005, Long et al. 2007, Jürgens \& Massana 2008). In studies of protist feeding, it is common to determine a single parameter, the 'grazing rate', using approaches such as the dilution technique (Landry \& Hassett 1982) and observation of the ingestion of fluorescently labelled prey (Sherr et al. 1987), among others (for reviews see Landry 1994, Sherr \& Sherr 1997). However, while the determination of grazing rates is invaluable, such measurements do not improve our understanding of why a prey type is ingested at a particular rate, or indeed why it might be rejected. To make simple predictions of how an ecosystem may respond to protistan grazing, we require an understanding of selectivity. Furthermore, as discussed below (see section 'Placing the observations in a larger context'), information on selective grazing is needed to produce mechanistic mathematical models that simulate the flux of nutrients within microbial food webs (Davidson et al. 1995a, Flynn 2006). This area of work is fundamental.

Our combined expertise leads naturally to the following structure. First, to allow us to communicate ideas and approaches, we develop a common framework for the processes associated with selective feeding. We then separate approaches to selective feeding behaviours into two categories: (1) those examining whole or-

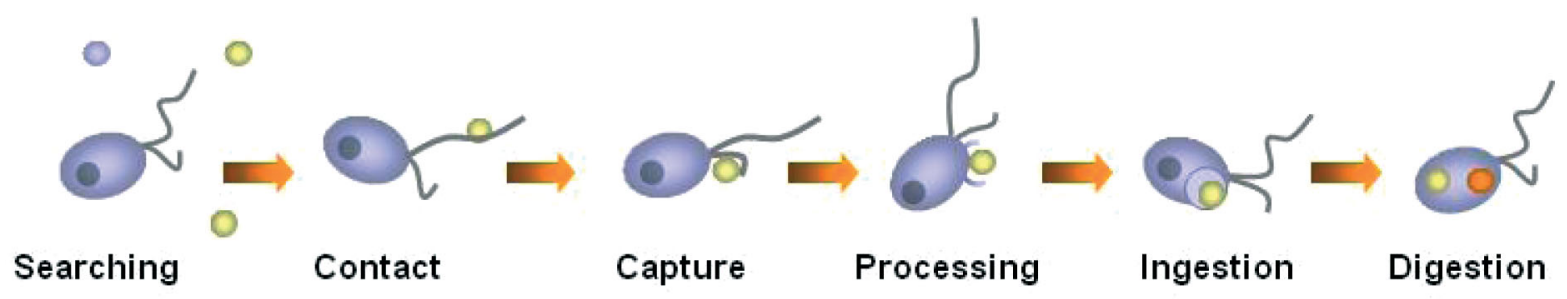

Fig. 1. Mechanistic steps in protistan prey capture that will potentially vary due to prey selectivity 
ganisms at the community, population, and individual levels and (2) those examining physiology and molecular attributes. Within each of these categories, we provide background and then suggest avenues for progress, using our conceptual framework as a focus.

\section{DEVELOPING AN APPRECIATION FOR THE MECHANISMS OF PROTISTAN FEEDING}

Phagotrophic protists have adopted a variety of methods to acquire food particles (Fenchel 1986, 1987, Jürgens \& Massana 2008), allowing their classification as filter feeders (e.g. ciliates and flagellates that produce feeding currents), diffusion feeders (e.g. heliozoa that radiate axopods with which prey collide), and raptorial-interception feeders (e.g. ciliates, flagellates, and naked amoebae that actively engulf prey). Once intercepted or collected, prey are individually ingested or packaged into food vacuoles, or, in the case of protists such as naked amoebae (Page 1988, Butler \& Rogerson 1997), foraminifera (Anderson et al. 1991, Murray 1991), radiolaria (Matsuoka 2007), and some heterotrophic dinoflagellates (Jacobson \& Anderson 1996, Hansen \& Calado 1999, Tillmann 2004), captured by whole cell engulfment using pseudopods that envelop prey, forming 'internal' or 'external' food vacuoles. Some species of dinoflagellates can also extract contents of their prey cells using a peduncle or feeding tube (Park et al. 2006, Jeong et al. 2007). Regardless of the specific feeding process, however, we can recognise several general mechanisms that combine to influence the selection of prey items by protists. These fundamental mechanisms provide us with an underlying conceptual framework.

\section{Mechanistic steps involved in selective protistan feeding}

Characteristics of prey cells or populations that potentially influence selective feeding by protists include the release of dissolved chemical cues, prey motility, prey biochemical composition or nutrient stoichiometry, cell surface characteristics, and finally prey size (e.g. Jürgens \& Massana 2008). Prey size is perhaps the most fundamental of these characteristics and clearly influences ingestion and selection (Andersen et al. 1986, Fenchel 1986, Epstein \& Shiaris 1992). The role of prey size can be further complicated by aggregation of prey particles, which may increase or decrease the probability of ingestion, such as in protistan feeding on colony forming Phaeocystis (Jakobsen \& Tang 2002). However, unsuitable prey at the large and small extremes of the size range are not behav- iourally deselected per se, as the prey are simply too big or too small to be available. In contrast, at intermediate prey:predator size ratios, prey size may be an important parameter in selection and capture, as the relative dimensions of prey and predator will influence contact probability, suitability for capture, and the food value of the prey. As substantial previous work has focused on prey size (e.g. Fenchel 1986, Jonsson 1986, Sanders 1988, Hansen 1992, Šimek \& Chrzanowski 1992, Boenigk \& Arndt 2002) our focus, which seeks to identify new insights related to feeding behaviour, will not re-examine these issues.

As is the case for metazoa, the act of grazing by protists is also composed of a number of separate but linked steps, each of which may be governed by one or many chemical, physical, or biological parameters. The number of steps could, in theory, be virtually infinite, but developing a series of discrete measurable points provides a practical, conceptual framework to base research on. To this end, we have extended the characterisation of heterotrophic flagellate feeding steps of Pfandl et al. (2004) to generate a schematic representation of protist food acquisition, incorporating six discrete steps: searching, contact, capture, processing, ingestion, and digestion (Fig. 1).

Searching. Searching for prey by motile predators is influenced by swimming speed and by changes in direction and frequency of turning, as this will alter the volume of water encountered. This behaviour may be affected by the distribution of prey (Fenchel \& Blackburn 1999) or predators (Berryman 1992), or by chemical cues (Buskey \& Stoecker 1988, 1989). Although chemotaxis and mechanoreception were first recognised in ciliates more than 100 yr ago (Jennings 1906), and protists are commonly observed to exploit patches of high prey density in situ (Taylor \& Berger 1980, Fenchel \& Jonsson 1988, Menden-Deuer \& Grunbaum 2006, Paffenhöfer et al. 2007), understanding the role of chemical-mediated prey location in prey selection, involving attraction to dissolved cues, remains in its infancy. Factors important in chemosensory attraction include proteins, amino acids, and other dissolved inorganic or organic nutrients (Rassoulzadegan 1982, Flynn \& Davidson 1993, Ferrier-Pagès et al. 1998, Davidson et al. 2005). Alternatively, other prey metabolites may deter grazing, including dimethylsulfide (Wolfe et al. 1997, Strom et al. 2003), dissolved free amino acids (Strom et al. 2007), and algal toxins (Hansen 1989, Kamiyama 1997, Tillmann 2003, Caron et al. 2004). Conceptually, chemosensory attraction, particularly to areas of elevated prey density, will reduce future searching time by the protist and increase the potential for predator-prey contact.

Contact. Contact probability between predator and prey will increase with increasing predator size (Flynn et 
al. 1996). However, this may be partly offset by reductions in swimming speed with increasing size (Crawford 1992). Moreover, prey cells are often not passive particles, and their motility will influence contact probability.

Capture. Capture (or prey handling) may be unsuccessful and reduce ingestion rates (Matz \& Jürgens 2005, Jakobsen et al. 2006). Some prey types can also exhibit behavioural defensive strategies, such as exopolymer formation and aggregation, that minimize contact (Pajdak-Stós et al. 2001). Finally, prey stickiness (Kiørboe \& Titelman 1998) and electrostatic or hydrodynamic factors are important at the micrometer scale; e.g. hydrophobicity may influence contact probability (Buskey 1997, Monger et al. 1999, Matz \& Jürgens 2001, Matz et al. 2002, Matz \& Jürgens 2005), as will the forces generated by the highly viscous, low Reynolds number environment in which protists exist (Pettitt et al. 2002).

Flynn et al. (1996) have proposed that it is possible to calculate the theoretical contact probability between predator and different prey in multi-species assemblages and use this as an index of selection or rejection of prey. However, the application of such an approach is made more difficult by the variability in successful prey capture, which, like searching or ingestion, may be influenced by chemical (receptor-ligand interaction) or mechanical factors (Seravin \& Orlovskaja 1977, Hausmann 2002, Wildschutte et al. 2004, Jakobsen et al. 2006).

Processing. Processing (or handling) of food, which can involve receptor-mediated recognition of particles (Wootton et al. 2007), can be one of the most active steps in overall food selection (Boenigk 2005, Berge et al. 2008).

Ingestion. Ingestion sensu strictu is limited by the morphological features of the predator, but unsuitable prey can be rejected (Stoecker et al. 1995, Boenigk \& Arndt 2000). To (partially) overcome such restrictions, a predator may have the capacity to enlarge its oral region (Kopp \& Tollrian 2003a, 2003b) or be adapted to digest cells extracellularly. However, in the case of radiolaria, feeding behaviour and diet are clearly related to skeletal morphology, and multi-segmented spumellarians ingest larger-sized prey compared to solitary spumellarians (Matsuoka 2007). Spinose species of planktonic foraminifera can handle and ingest actively swimming metazoa, whereas non-spinose species may not be able to capture and hold active metazoa (Anderson et al. 1991). The inability of tube-feeding dinoflagellates to penetrate rigid cell coverings may explain their reduced feeding on diatoms and thecate dinoflagellates (Berge et al. 2008). In summary, morphology and structure play a major role in ingestion.

Digestion. Digestion appears to be actively regulated, and unsuitable (possibly indigestible) material can be prematurely ejected by some protists, such as flagellates (Flynn \& Davidson 1993, Hansen \& Calado 1999, Boenigk et al. 2002). For some ciliates, in contrast, indigestible material remains within the food vacuoles for its lifespan (Fok et al. 1982), even though the lifespan of vacuoles containing high amounts of indigestible materials may be shorter than that of vacuoles containing digestible prey (Boenigk \& Novarino 2004). However, the majority of ingested prey is digested, although differential digestion occurs in protists: for example, gram-negative bacteria are generally digested more rapidly than gram-positive cells (Gonzalez et al. 1990, Weekers et al. 1993, Ronn et al. 2002). As discussed below (see section 'Examining behaviours at the population and single cell levels'), although digestion is not strictly part of food selectivity, for experimental reasons it may alter our perception of selective feeding and must, therefore, be considered.

\section{Synthesis}

Selective grazing by protists can be represented by six steps (Fig. 1), each of which can be inferred from theory. Developments in microscopy and chemistry have also elucidated their existence, as briefly presented above. However, the isolation and parameterisation of the mechanisms that underpin selective grazing and its role within microbial food webs remain major challenges. The design of experiments that can quantify the response of, for example, prey capture and processing to external stimuli remains problematic with the experimental tools currently at our disposal. With this in mind, we present and discuss some of the avenues of study that need attention.

\section{EXAMINING BEHAVIOURS AT THE POPULATION AND SINGLE CELL LEVELS}

Two major approaches have been used to investigate protist feeding behaviours at the organism level: population-community studies and single cell observations. These distinct approaches have their respective strengths and weaknesses, but there are common areas for development. In this section, following the terminology and concepts outlined above, we summarize the main directions that laboratory and field studies have followed over the last several years and then provide some suggestions for the direction of future work.

\section{Population studies in the laboratory}

Typically, most laboratory experiments have focused on population responses of easily cultured taxa, using 
batch cultures of varying sizes (but see section 'Laboratory approaches towards individuals'). Searching has been explored using preference chambers and needle assays to demonstrate en masse movement of protists, either towards or away from stimuli such as live prey, predators, and chemical cues (Leick et al. 1994, Fenchel 2004, Martel 2006, Leick \& Lindemose 2007). An alternative method for the indirect determination of parameters such as searching rate and handling time (a combination of contact and capture) is to infer them from the results of experiments that examine functional responses (i.e. grazing rate vs. prey concentration). Response curves are fit to the data, and grazing parameters are determined from mechanistic functions (e.g. Fenchel 1984). This indirect approach can be applied to multiple prey species to assess capture success, as has been done by Verity (1991). However, such studies are few, partially because of their complexity but also because of the difficulty of identifying prey types in mixtures.

The most common laboratory approaches to assess grazing behaviour have used a variety of natural and surrogate prey (discussed in more detail in 'Field approaches towards estimating population-community responses) and have measured either prey removal/ depletion or prey uptake, both of which determine ingestion rates. Prey removal is typically measured either directly (e.g. microscopy, electronic particle counting; Flynn \& Davidson 1993) or indirectly (e.g. using prey fluorescence as a proxy for prey abundance). Through such experiments, it is possible to recognise that protists possess prey-dependent ingestion rates (e.g. Eccleston-Parry \& Leadbeater 1994, Parry 2004), indicating variation in either contact or capture. However, ingestion rates represent nearly the end-point of the entire feeding process (Fig. 1); alone, they do not allow recognition of the stages at which feeding behaviour changes. Ingestion rates therefore fail to evaluate the individual processes involved in protist feeding, and like all laboratory work they do not represent the natural environment and may mask or fail to include external factors that alter selectivity (e.g. chemical cues, turbulence regime, light intensity and composition; see section 'Examining behaviours at the molecular and physiological levels').

\section{Field approaches towards estimating population-community responses}

In field experiments, a natural community, or a defined size-fraction of a community, is typically contained within a chamber that is then incubated in situ. These chambers may be non-permeable (e.g. bottles, plastic bags; Sherr \& Sherr 1993) or permeable (dialy- sis bags, diffusion chambers; Ferrier-Pagès \& Rassoulzadegan 1994, Weisse 1997). In both cases, natural cues that may alter selectivity are included to a lesser or greater extent. As with laboratory studies, both prey depletion and prey uptake approaches have been applied to examine ingestion and prey selectivity by natural assemblages, and like laboratory work, the findings are generally limited to estimates of ingestion, often obviating the potential to examine the specific steps (Fig. 1) associated with selectivity. In addition, the selectivity observed during depletion experiments obviously represents the sum of specific selectivity behaviours of all components of the community.

Some experiments examine the reduction in natural prey (e.g. the dilution approach; Landry \& Hassett 1982), where prey depletion is normally observed as a bulk measurement (e.g. chlorophyll $a_{\text {; }}$ Stelfox-Widdicombe et al. 2000). In theory, both predators and prey might be directly identified. Prey selectivity could then be speculated on. However, such experiments would be difficult to perform with sufficient resolution to determine specific behaviours, as it is exceedingly difficult to assess specific responses of predators and prey in natural samples, and the discrete processes (Fig. 1) associated with the end result — ingestion — cannot be determined.

Other field experiments have measured grazing through the uptake of inert particles, such as heatkilled fluorescently-labelled prey (FLP), produced from either monocultures or a mixed prey community (Epstein \& Shiaris 1992, Sherr \& Sherr 1993, Šimek et al. 2000, Cleven 2004). These experiments also mostly fail to examine prey selectivity, as the resolution provided by staining specific prey types is insufficient to resolve preferences (see section 'Identifying prey').

In the case of larger-sized phagotrophic protists, such as foraminifera, studies examining fatty acid biomarker (Suhr et al. 2003) and cell carbon isotopic composition (Nomaki et al. 2006) of individual cells have demonstrated that certain taxa feed selectively. However, these studies do not provide information on why particular prey types are positively or negatively selected.

\section{Laboratory approaches towards individuals}

The observation of individual protistan behaviours has a long history (Ehrenberg 1838), but it is only relatively recently that observational techniques have allowed detailed quantitative assessments of prey selectivity (e.g. Holen \& Boraas 1991, Boenigk et al. 2001b, Pfandl et al. 2004). Video observations have been used to directly measure individual feeding process stages, such as contact, capture, processing, ingestion, and digestion, particularly in sessile flagel- 
lates (Boenigk et al. 2001a,b, Pfandl et al. 2004, Boenigk 2005), drifting or substrate-attached protists (Hausmann 2002), and planktonic tintinnids, which can be trapped by immobilising their lorica (Taniguchi \& Takeada 1988, Stoecker et al. 1995). However, these studies are rare and exceedingly difficult to conduct on most motile species (but see Strom \& Buskey 1993, Berge et al. 2008). Furthermore, few of these studies have been performed using different live prey organisms (Wu et al. 2004, Jezbera et al. 2005).

An exciting new direction for observations of individuals is the ability to track non-sessile cells. In principle, the observation of feeding by individual free-swimming protists has been successfully demonstrated: the feeding current (searching) of swimming protists has been analysed for the flagellates Paraphysomonas and Pteridomonas (Christensen-Dalsgaard \& Fenchel 2003), and the feeding process and food selection (contact and capture) have been investigated for Cyclidium glaucoma by restricting the individual observation time to short intervals (Pfandl 2003). Furthermore, video microscopy, with computer-aided motion analysis, has indicated that protist searching behaviour can be both chemotactic (stimulus-oriented, directed movement) and chemokinetic (stimulus-induced, non-directed movement) (Leick \& Lindemose 2007, Strom et al. 2007), as well as being governed by fluid mechanics (Jakobsen et al. 2006). Video microscopy can also be used to observe feeding mechanisms involved in the capture of different prey types. For instance, in the case of 2 mixotrophic dinoflagellates, Gonyaulax polygramma ingests smaller-sized prey by engulfment through its apical horn, while employing its sulcal area for larger-sized prey (Jeong et al. 2005), while Karlodinium armiger uses tube-feeding for larger or thecate prey and engulfment of prey or an incomplete extension of the feeding tube for smaller prey (Berge et al. 2008). Developments in optical and computer-driven technology associated with the direct observation of unimpeded protists should provide exciting avenues for future study.

Finally, although the use of fluid mechanical signals in prey detection by metazoa (e.g. Gilbert 1987, Kirk \& Gilbert 1988) and fluid mechanical predator detection by protists (e.g. Jakobsen 2002) is well known, the role of fluid mechanical prey detection by heterotrophic protists is in its dawn. In a recent study, evidence was presented to show that the raptorial ciliate Mesodinium pulex used equatorial cirri (modified cilia) as functional fluid mechanical sensors in the same fashion as the setae on metazoan antennae. In this way, the ciliate discriminated between prey sizes and localised the direction of oncoming prey through fluid mechanical signals (Jakobsen et al. 2006). Clearly, there is a continued need to discern between chemical and mechanical cues in the selective feeding of protists.

\section{Future directions}

In studies of selective feeding, as in most field and laboratory studies, there is a classic dichotomy between the high precision and poor accuracy of laboratory estimates and the higher accuracy and relatively poor precision of field estimates. And, as is typical in most ecological research, it is through a coupling of both laboratory and field work that a closer approximation of reality will be found. We have provided an overview of some of the recent developments in our understanding of prey selectivity at the populationcommunity and individual levels; from these we see the following key issues arising.

Recognising the effect of incubation times. Above, we mentioned a number of methods used to incubate samples to determine ingestion or grazing rates. Preyuptake experiments conducted in the field or laboratory may evaluate intra- and inter-specific variation within populations and communities, respectively. However, such prey-uptake experiments generally involve short-term incubations, so prey-induced changes (e.g. by morphological or chemical factors) in feeding behaviour (e.g. enzymatic induction mechanisms to detect or digest relatively 'recent prey') may not be detected. At present, prey-depletion experiments allow the evaluation of prey selection in population-community studies. Because prey-depletion experiments generally involve long-term incubations, prey-induced changes in feeding behaviour may occur, but may not be detected (e.g. switching behaviour). Recognising the limitations of these experiments and potentially developing new means to elucidate behaviours is clearly an avenue for future work.

Accounting for the effects of digestion. Although few studies have focused on digestion (the final step in our process, Fig. 1), it may require careful assessment for studies of selectivity. Following ingestion, prey will start to be digested and prey cells will become less visible and detectable in the protist food vacuoles over time. This in turn may lead to underestimates of calculated ingestion rates for highly digestible prey and the impression that the least digestible prey have been selected for, because only they are still visible in the food vacuoles. 'Short' incubation periods have been advocated to prevent such complications, but these periods will depend on the type of predator and prey, as digestion will still occur at different rates. Egestion of indigestible or hardly digestible prey may occur within minutes after ingestion, reducing the incubation time for unbiased food uptake experiments to very short intervals (Boenigk et al. 2001b, 2002). With so little information regarding the digestive stage of the protist feeding process (e.g. Fok et al. 1982, Dolan \& Šimek 1997, 1999, Boenigk et al. 2001b, 2002; 
Matz et al. 2004, Jezbera et al. 2005), it is currently difficult to design prey uptake experiments that account for this parameter effectively; again, we see this as a valuable avenue for continued study.

Identifying prey. Protists exhibit preferences associated with surrogate and natural prey. Although some work has been conducted in this direction (e.g. Montagnes \& Lessard 1999), it is clear that this is also an avenue for further study, through both laboratory and field experiments, as previously outlined. In many instances, surrogate prey such as plastic beads and heat-killed prey (Fenchel 1986, Sherr \& Sherr 1993) are discriminated against (Pfister \& Arndt 1998, Boenigk et al. 2002, Pickup et al. 2007), and their use will bias selectivity experiments; consequently, they are not an ideal tool. However, experiments examining the selection of different live prey items are less common, because present means for the identification of prey types are limited and time-consuming (e.g. microscopy). The study of selective feeding on live prey with distinct morphological or fluorescent signatures (e.g. heterotrophic flagellates, various distinct algae) is possible (Verity 1991, Flynn et al. 1996). However, these features are not sufficient to resolve all species, and for small prey of similar shape the problem is even more severe (Wu et al. 2004).

To resolve this issue, techniques such as density gradient gel electrophoresis (DGGE) and fluorescence in situ hybridization (FISH) promise to be useful tools to monitor changes in prey community profiles (Ronn et al. 2002) or to detect prey species within the protist food vacuoles (Jezbera et al. 2005, 2006, Šmek et al. 2007). Developments in flow cytometry may also allow the rapid discrimination between prey groups (Vázquez-Domínguez et al. 2005), and through cell sorting in combination with molecular or chemical tracers they may allow the physical separation of prey and predators. The few studies that have employed such techniques provide evidence for prey selectivity or suggest the potential to do so. We see this as a sensible avenue of technological exploration.

Improving video surveillance. As indicated above, investigations that study selective feeding by individual protists are largely restricted to sessile or immobilised protists. Selective feeding in motile individuals, which is more relevant in freshwater and marine pelagic systems, has rarely been investigated at the single cell level, due to methodological limitations (but see Pfandl 2003). Individual observations are, however, crucial for the assessment of the basic mechanisms of food selection. A major issue is to overcome the current methodological limitations and to extend video observations to motile species. With recent developments in microprocessor-controlled automatic imaging systems and software technologies, we consider the continued ap- plication of methods presently applied to observing behaviours of metazooplankton and protists (Kiørboe et al. 1996, 2004, Jakobsen et al. 2006, Strom et al. 2007) to be an essential future activity.

Determining the relevance of fluid mechanical signalling. Understanding the role prey behaviour plays in protist feeding requires broad experimental studies of swimming behaviour of prey (e.g. bacteria, flagellates), coupled with predator-prey encounter studies. We suggest that, using recently developed methods and following the example of others (e.g. Jakobsen \& Hansen 1997, Jakobsen 2002, Jakobsen et al. 2006), continued emphasis should be placed on distinguishing mechanical signals from other stimuli for selective feeding. In addition, the evaluation of mechanisms involved in the sensory transduction of mechanical stimuli should be addressed.

Examining ecologically relevant species and conditions. Regardless of whether experiments were performed on individual cells or populations, most laboratory studies have, pragmatically, used easily cultured predators and prey, and many studies use high prey abundance relative to in situ levels. 'Weed' species are ideal for examining variability between individuals or between populations, as well as for the study of trends in prey selectivity and major mechanisms underlying the process (Nanny 1980). However, this approach does not necessarily lend itself to predicting trends in natural environments. Furthermore, protists may exhibit specific patterns of prey selectivity in laboratory experiments when they are acclimated to saturating levels of optimal prey that may not reflect in situ conditions. It may seem axiomatic, but there is a continued need to experiment with such weed species that are more difficult to culture, both predator and prey, under near natural conditions. Continued efforts must, therefore, be made to develop means to culture these species, and funding agencies should recognise the need to develop these fundamental methods.

Coupling lab and field work. Finally, there is a continued need to critically assess and verify conceptually correct conclusions based on laboratory cultures with field measurements. We strongly support the comparison of laboratory and field studies, ideally on nonweed species (see section 'Examining ecologically relevant species and conditions'), using common methodologies. To this end, we also suggest that laboratory work should attempt to better mimic natural abiotic (e.g. turbulence, temperature, light intensity and spectral composition) and biotic conditions that might control selective feeding behaviour; for instance, future laboratory studies might examine selective feeding in the presence of mixed prey, using new methods for prey identification (see section 'Identifying prey'). 


\section{EXAMINING BEHAVIOURS AT THE MOLECULAR AND PHYSIOLOGICAL LEVELS}

Experiments examining protist behaviours at the physiological level have mainly focused on changes in feeding selectivity associated with predator nutritional state (Jürgens \& DeMott 1995, Christaki et al. 1998, Boenigk et al. 2002). We concentrate on the results of these experiments and pay particular attention to both molecular mechanisms and prey physiological effects on selective feeding behaviour. We start by introducing molecular mechanisms potentially involved in selective feeding, and highlight the difficulty of studying these mechanisms in isolation.

The molecular detection of prey by protists can occur at 4 of our 6 steps (Fig. 1): during searching, in response to dissolved chemical cues, and then during capture, processing, and ingestion, all three of which involve surface recognition of prey. We discuss primarily receptor-mediated processes involved with these 4 steps, although it is worth noting that sensing of dissolved chemical stimuli can also involve alternative mechanisms. For example, rather than binding to cell surface receptors, the attractant ammonium chloride diffuses as ammonium across the cell membrane of the ciliate Paramecium, which results in altered swimming behaviour (Davis et al. 1998).

Feeding experiments using predatory ciliates demonstrate the involvement of molecular mechanisms in predator-prey interactions: predatory ciliates locate (search for) their ciliate prey by responding to dissolved proteinaceous compounds released by the latter (Morelli \& Verni 1996). Prey ciliates can, in turn, detect predator-released substances that stimulate them to transform into predator-resistant phenotypes by deploying antipredator structures such as spines, keels, or ridges (Wicklow 1997, Kuhlmann et al. 1999, Jakobsen \& Tang 2002), thus reducing risk of capture.

Although both carnivorous (Morelli \& Verni 1996) and herbivorous (Strom \& Buskey 1993) protists show behavioural responses to chemosensory signals released by their prey, it remains difficult to determine how this type of chemoreception is used to select between different prey species because other prey variables may influence prey contact and capture. For example, Buskey (1997) demonstrated that a pallium-feeding dinoflagellate exhibits a distinct preference for diatoms over dinoflagellates when offered a mixed assemblage. His experiments provide indirect evidence that chemosensory perception influences the feeding selectivity for this predator, with the dinoflagellate exhibiting a behavioural response (searching) to chemosensory signals associated with the phytoplankton prey. The study also demon- strated, however, that other factors in addition to chemosensory behaviour play an important role in feeding selectivity, with prey motility acting as a key selection parameter in successful capture: Buskey (1997) observed that the dinoflagellate frequently lost contact with the highly motile dinoflagellate prey before capture occurred, but this was not observed with the non-motile diatoms. Thus, we still require methods to dissect the individual feeding processes (Fig. 1).

Quantifying the extent to which cell surface recognition (capture and processing) is used to select between different prey species also remains problematic. Although the ability of protists to discriminate between particles based on surface biochemical composition has been demonstrated using beads coated with different compounds (Matz et al. 2002, Wootton et al. 2007), these experiments fail to indicate the direct use of these mechanisms in prey selection.

\section{Experimental approaches and interpretations}

Unlike community studies, experiments investigating how predator and prey physiology influences selective feeding behaviour have focused on protist cultures rather than natural assemblages, allowing better assessment of the mechanisms. These studies can be separated into two main categories, relating to predator or to prey physiology, depending on the perspective of the encounter.

Changes in selective feeding relating to predator physiology. The degree to which predator satiation and prey concentration affect selective feeding can vary considerably between different predator species. For the bacterivorous interception-feeding flagellates studied by Jürgens \& DeMott (1995) and Boenigk et al. (2001a), increased selectivity occurred after acclima-

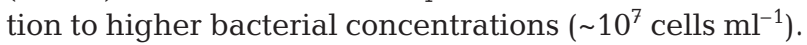
At these high prey abundances, typically greater than those found in natural pelagic environments, several flagellate species actively selected for bacteria over latex beads; however, discrimination was not observed at lower concentrations. In contrast, Christaki et al. (1998) observed that two ciliate species exhibited a higher degree of selectivity at limiting food concentrations. Under these conditions, both ciliates displayed greater particle discrimination when fed beads with different surface properties, although the degree and direction of selectivity differed between species. Clearly, there is interaction between factors such as prey concentration and selectivity. In addition, protists display taxon-specific responses. To evaluate the latter, it is necessary to examine at which step selectivity occurs. 
The mechanisms behind changes in feeding selectivity with predator nutritional state are poorly understood, but could be linked with changes in prey recognition at the capture or processing stages (Boenigk et al. 2002). Based on the limited work on the biochemical mechanisms for prey recognition by free-living protists, carbohydrate-protein interactions appear to play an important role. In certain amoebae, for example, galactose/N-actetyl-galactosamine-binding and mannose-binding lectins are involved in the attachment (capture) and uptake (processing and ingestion) of prey (Allen \& Dawidowicz 1990, Venkataraman et al. 1997). Furthermore, the dinoflagellate Oxyrrhis marina can use a $\mathrm{Ca}^{2+}$-dependent mannose-binding lectin to recognise (capture) and phagocytise (process and ingest) prey (Wootton et al. 2007). Now that these receptors have been identified, the next logical avenue is to determine their specific role in selective feeding and investigate changes in receptor expression with predator physiological state.

Changes in selective feeding relating to prey physiology. The C:N:P ratio is often used to indicate nutritional stress in phytoplankton and bacteria. Some protists may discriminate between prey of different nutritional state and elemental ratio; for example, flagellates may ingest N-replete (low C:N ratio) phytoplankton prey at a greater rate than N-deplete cells (Verity 1991, Flynn et al. 1996, John \& Davidson 2001). Flagellates may also discriminate between bacterial prey based on different $\mathrm{C}: \mathrm{P}$ and $\mathrm{N}: \mathrm{P}$ ratios, with low $\mathrm{C}: \mathrm{P}$ bacteria being ingested at higher rates (Shannon et al. 2007).

Again, the mechanisms behind such selective feeding are poorly understood. Although molecular mechanisms may be involved, there is no direct experimental evidence to demonstrate this at present. For example, cell surface $\mathrm{N}$-actetyl-glucosamine expression of a photosynthetic dinoflagellate changes with N-status of the cell (Kremp \& Anderson 2004). Because cell surface sugar moieties appear to act as ligands for predatory protist lectins (Wootton et al. 2007), the variable expression of cell surface carbohydrate residues by the prey may affect cell surface recognition (capture and processing) by the protist predator. This has, however, yet to be studied experimentally using live prey. The release of signal molecules, such as amino acids, may also be expected to change with the nutritional status of phytoplankton cells (Granum et al. 2002), because amino acids act as attractants for many protists, including flagellates and ciliates (e.g. Sibbald et al. 1987). However, there is presently no direct evidence demonstrating that chemoreception (searching) is responsible for changes in selective feeding in relation to prey nutrient stoichiometry.
Other prey variables that potentially affect this type of selective feeding behaviour have been mentioned above (see section 'Developing an appreciation for the mechanisms of protistan feeding') and include the release of defence metabolites, changes in prey size, motility, charge, and, hydrophobicity (Matz et al. 2002, Pohnert et al. 2007). How these factors vary with prey physiological state, and hence affect selective feeding, clearly requires further investigation to better understand observed selective feeding behaviour.

\section{Future directions}

It is evident that a better understanding of the underlying biochemical mechanisms determining selective feeding behaviour is required. Within the last 2 decades, substantial progress has been made in identifying molecular aspects of cell recognition and prey detection in model protist species. However, we still have a limited understanding of the relevance of these mechanisms in a broader ecological context. To address this, we suggest the following avenues for future work.

Understanding the mechanisms behind the detection of dissolved chemical cues. Biochemical, molecular, and genomic studies have enabled the identification of many molecular components that participate in the regulation of chemotaxis, e.g. for the social amoeba Dictyostelium (Parent \& Devreotes 1999, Chung et al. 2001, Jin \& Hereld 2006) and for the model ciliate Paramecium (Van Houten et al. 2000, Bell et al. 2007). A similar approach needs to be pursued for a broader range of environmentally relevant protists, focusing on the determination of the ecological and biogeochemical relevance of chemosensory behaviour (e.g. Hartz et al. 2008). We see this cross-disciplinary avenue of research as an opportunity for future collaboration of researchers in a variety of fields.

Unravelling the mechanisms involved in cell surface recognition. Initial work has been undertaken to improve our understanding of cell surface biochemical prey recognition by protists. Several potential phagocytic receptors and prey ligands to which they bind have now been identified for protists (Allen \& Dawidowicz 1990, Venkataraman et al. 1997, Sakaguchi et al. 2001, Wootton et al. 2007). Further work should involve the identification and purification of additional receptors, and subsequent characterization of their role in selective feeding. As genomes of an increasing number of protists are being sequenced, proteomic analysis of phagosomes and cell surface proteins should prove useful in revealing potential prey recognition receptors. This technique has already enabled an increased understanding of the molecular mechanisms behind phagocytosis in the model protists 
Tetrahymena, Entamoeba, and Dictyostelium (Rezabek et al. 1997, Okada et al. 2005, Jacobs et al. 2006). Again, we see the next step as applying and adapting techniques to more ecologically relevant taxa, first in the laboratory and then, once appropriate methods are established, in the field.

Determining the relevance of these mechanisms in selective feeding. Identification and characterisation of receptors and ligands involved in the response to dissolved chemical cues and in cell surface recognition will improve our ability to study molecular aspects of feeding in isolation (Fig. 1). We may find that, for many protists, molecular mechanisms mainly act to increase feeding efficiency on live prey in general and do not play a major role in determining selection between different prey species. For highly specialized protist predators, however, biochemical prey recognition is likely to drive feeding behaviour and prey selectivity. For instance, dinoflagellates often exhibit a high degree of prey specificity (Hansen \& Calado 1999, Tillmann 2004); e.g. the mixotroph Fragilidium subglobosum feeds exclusively on species from the genus Ceratium, preferring Ceratium tripos to Ceratium furca or Ceratium fusus (Skovgaard 1996, Hansen \& Nielsen 1997), and the mixotrophs Ceratium and Dinophysis feed predominantly on ciliates (Jacobson \& Andersen 1994, Smalley et al. 1999). The mechanisms behind these extreme examples of selectivity are presently unknown. Planktonic host-parasite interactions are also expected to involve biochemical cell recognition, with one strain of the endoparasitic dinoflagellate Amoebophrya sp. only being capable of infecting species of the genus Alexandrium when presented with a range of potential dinoflagellate host species (Kim 2006). Without further knowledge of the mechanisms involved in prey recognition, we lack a fundamental understanding of how protist predators feed and hence will experience difficulties in applying the findings of isolated laboratory and field experiments to natural assemblages as a whole. It is clear that the environmental implications of this research area require continued consideration.

\section{PLACING THE OBSERVATIONS IN A LARGER CONTEXT}

The past several decades of research on microbial food webs and, specifically, on protist selective feeding have dramatically changed our perception of microbial feeding interactions. Protists are increasingly recognised as highly specialised consumers. Having unravelled so many mysteries of selective feeding by protists, we are now beginning to place the pieces into context. In this final section, we have identified several broad avenues towards this ultimate goal.

\section{Towards a general picture}

First, we must identify general patterns and dominant peculiarities related to feeding behaviours. However, in contrast to our recognition of the great diversity of protists (Vaulot et al. 2002, Baldauf 2003), current knowledge of different feeding behaviours remains largely based on limited field and laboratory experiments, focusing on either functional groups (Šimek et al. 2000) or few laboratory weed species (e.g. Fenchel 1984, Boenigk \& Arndt 2000). The relevance of the discovered selection mechanisms must be critically evaluated using prey organisms that are important in the field (Wu et al. 2004). Again, there is an ultimate need for isolating and culturing many more protist strains as a basis for in-depth investigations of specific behaviours and selection mechanisms. We encourage culture collections, researchers, and funding agencies to recognise this need.

\section{Linking food selection with the natural environment}

In situ feeding behaviour in phagotrophic protists can be regulated both by their internal environment (e.g. feeding ultrastructures, chemoreception capacities, physiological state, feeding history) and the external environment. The external environment includes variables dependent on the availability and characteristics of prey (e.g. abundance, size, mobility, biochemical composition, physiological state, surface characteristics, grazing resistance properties) and variables independent of prey. Among the latter, temperature (Sherr et al. 1988, Tobiesen 1990), light intensity (Stoecker \& Guillard 1982, Hansen \& Nielsen 1997, Strom 2001), ultraviolet radiation (Hessen et al 1997, Ochs \& Eddy 1998), nutrient concentrations (Ucko et al. 1994, Legrand et al. 1998, Granéli \& Johansson 2003), turbulence (Shimeta et al. 1995, Peters et al. 1996, Dolan et al. 2003), suspended non-grazable particles (Hansen et al. 1991, Boenigk \& Novarino 2004), and particularly bioactive compounds and toxic compounds (Hoffman \& Atlas 1987, Al-Rasheid \& Sleigh 1994) can regulate feeding activity in phagotrophic protists, but their role in selective feeding has rarely been specifically investigated. Most of these abiotic external variables can either directly affect the feeding behaviour of phagotrophic protists, or indirectly influence them through changes upon their prey. These external variables can potentially impact all 6 discrete feeding phases of phagotrophic protists (Fig. 1), and, in case their impacts are prey-dependent, feeding selectivity will also be altered. If we plan to extrapolate the findings of laboratory and field studies on protist selective feeding to the natural aquatic environment, then we must attempt to better mimic the variables that con- 
trol selective feeding behaviour. Therefore, although our assessment has focused primarily on the organisms, we remind the reader not to forget the external environment.

\section{Linking food selection with food web effects}

Once the key components and controls have been adequately identified, the next big issue will be to place food selection behaviours (individual and general) into the context of food web interactions. In situ, the protistan grazer community and related aspects of its prey selectivity are obviously shaped both by inherent bottom-up factors and predation pressure on protists themselves. Furthermore, once we recognise the mechanisms associated with selectivity, we will be better prepared to examine how abiotic factors (turbulence, light, temperature, pH) may alter behaviours. The interplay of these factors can regulate community dynamics and selectivity of protists in situ (e.g. Šimek et al. 2006). Ultimately, these aspects must not be forgotten in either field studies or model simulations of ecosystem dynamics.

Historically, mathematical ecosystem models have paid relatively little attention to protist grazing, never mind selectivity (Davidson 1996), but authors such as Flynn (2006) argue strongly for the inclusion of mechanistic processes such as protist selective grazing in such models. A small suite of studies have attempted to use models to examine particular aspects of selective grazing with a focus on microbial cell size distribution and predator-prey dynamics (Kiefer \& Berwald 1992, Strom \& Loukos 1998). Such attempts need to be extended, specifically considering the molecular and behavioural basis of food selection as generally outlined above.

An operational model of selective protist grazing based on our schematic representation in Fig. 1 would contain a very large number of parameters, which would require considerable advances in experimental technique, as discussed above (see sections 'Examining behaviours at the population and single cell levels' and 'Examining behaviours at the molecular and physiological levels'). An initial challenge to modelling will, therefore, be to conduct sensitivity analyses of simple models of selective grazing, based on structures similar to those outlined above (Fig. 1), to assess the parameters most critical to model performance. This in turn will guide future experimental efforts. Therefore, we encourage and applaud the continued interdisciplinary collaborations of modellers and experimental scientists who integrate potentially important subtleties such as feeding behaviour into the larger ecosystem context.

\section{From behaviour to element flow}

Ultimately, many ecosystem studies focus on the flow of biomass, typically represented by carbon, nitrogen, or phosphorus. In this paper, we have primarily dealt with prey selection based on taxa. Even more complex, however, are the links between protist food selection and element transfer in food webs. For instance, differential digestion, element conversion, and metabolic pathways will further modify the feeding interactions. With respect to nutrition and element flow, these factors must ultimately be considered as part of the selection process (Boenigk et al. 2002, Mitra \& Flynn 2005, Davidson et al. 2007).

Some modelling work has addressed these issues of element flow with specific relevance to selectivity. For example, Stolte et al. (2007) modelled the effect of allochthonous dissolved organic matter on grazing on poorly edible phytoplankton, and Davidson et al. (1995a, 1995b) used the C:N ratio of prey and predator as indices of the potential for selectivity. Furthermore, recent theoretical work has developed models that incorporate aspects of protistan selective grazing; e.g. Mitra et al. (2003) and Mitra \& Flynn (2005) developed models that incorporate factors such as variable maximum ingestion rate, assimilation efficiency, and 'stoichiometric modulations'. We consider the extension of such approaches to be a logical avenue for future progress in ecosystem food web ecology. However, we emphasise two caveats: the modelling must not be conducted in isolation; it requires sound parameterisation by laboratory work and continued 'ground-truthing' through field studies.

\section{Experimental design}

Underlying laboratory and field studies as well as model applications of concepts and parameters, we must remember that there is a need for good experimental design and data analysis. Although not explicitly dealt with in this paper, we know, from our collective experiences, that an unacceptable portion of the work on selective feeding (some published and much unpublished) is based on an inadequate foundation (i.e. poor experimental design and inappropriate numerical-statistical analysis). Here, we have encouraged several avenues for experimentation and observation on protistan feeding behaviours, in places suggesting state-of-the-art technologies, many of which will produce copious data. We also encourage continued careful design of experiments, e.g. considering pseudoreplication (Hurlbert 1984), the number of replicates (Roa 1992), and even whether or not to replicate at all (Montagnes \& Berges 2004). 


\section{From mechanisms towards selection}

In conclusion, we emphasise that there is a need to identify the key processes that are applicable across systems; i.e. the comparison of free-living protist food selection with that of metazoa and parasitic protists. Identifying similarities and dissimilarities and the fundamental mechanisms behind these patterns will certainly reveal key underlying processes and critical differences. We have not dwelt on the massive literature on selective feeding that exists beyond the protists (e.g. Brooks \& Dodson 1965), but this must always be considered, and the uninitiated reader is encouraged to do so. However, once general selection mechanisms (e.g. Fig. 1) are identified, quantified, and considered in a larger context, the next challenge will be to analyse their impact on in situ feeding interactions (Jezbera et al. 2006). Continued interaction and dialogue between researchers studying selective feeding in the laboratory and field is essential, and we thank SAME 10 for providing the opportunity for such a discourse and encourage its continuation, both informally and formally, through other meetings.

Acknowledgements. We thank the organizing committee of SAME 10 (10th Symposium on Aquatic Microbial Ecology, Faro, Portugal, September 2007), particularly its coordinator $\mathrm{H}$. Galvão and the local organizing committee. We thank E. Wooton, J. Thurman, C. Dixon, and H. Jakobsen for their constructive comments. We also thank P. del Giorgio for his encouragement and guidance in assembling this document. The following funding agencies provided support for our participation in this work: J.B. was partially funded by the FWF grant P 19706; K.D. was partially supported by the SAMS/ NERC Oceans 2025 program; M.M. was supported by the projects PAPIIT IN207206 and CONACYT 52387; D.J.S.M was partially supported by the British Council; K.S. was partially supported by the GACR under research grant 206/08/0015; J.D.P. was supported by the Leverhulme Trust research grant F/00 185/S and the Faculty of Science \& Technology Travel Fund, Lancaster University; E.C.R. was partially supported by NERC grant NER/M/S/2003/00052.

\section{LITERATURE CITED}

Allen PG, Dawidowicz EA (1990) Phagocytosis in Acanthamoeba. 1. A mannose receptor is responsible for the binding and phagocytosis of yeast. J Cell Physiol 145: 508-513

Al-Rasheid KAS, Sleigh MA (1994) The effects of heavy metals on the feeding rate of Euplotes mutabilis (Tuffrau, 1960). Eur J Protistol 30:270-279

Andersen OK, Goldman JC, Caron DA, Dennett MR (1986) Nutrient cycling in a microflagellate food-chain: III. Phosphorus dynamics. Mar Ecol Prog Ser 31:47-55

Andersen OR, Lee JJ, Faber WW Jr (1991) Collection, maintenance and culture methods for the study of living foraminifera. In: Lee JJ, Anderson OR (eds) Biology of Foraminifera. Academic Press, London, p 335-358

Baldauf SL (2003) The deep roots of eukaryotes. Science
300:1703-1706

> Bell WE, Preston RR, Yano J, Van Houten JL (2007) Genetic dissection of attractant-induced conductances in Paramecium. J Exp Biol 210:357-365

Berge T, Hansen PJ, Moestrup Ø (2008) Feeding mechanisms prey specificity and growth in light and dark of the plastidic dinoflagellate Karlodinium armiger. Aquat Microb Ecol 50:279-288

$>$ Berryman AA (1992) The origins and evolution of predatorprey theory. Ecology 73:1530-1535

Boenigk J (2005) Some remarks on strain specificity and general patterns in the ecology of Spumella (Chrysophyceae). Nova Hedwigia 128:167-178

> Boenigk J, Arndt H (2000) Particle handling during interception feeding by four species of heterotrophic nanoflagellates. J Eukaryot Microbiol 47:350-358

Boenigk J, Arndt H (2002) Bacterivory by heterotrophic flagellates: community structure and feeding strategies. Ant Leeuwenhoek 81:465-480

Boenigk J, Novarino G (2004) Effect of suspended clay on the feeding and growth of bacterivorous flagellates and ciliates. Aquat Microb Ecol 34:181-192

> Boenigk J, Matz C, Jürgens K, Arndt H (2001a) Influence of preculturing conditions and food quality on the ingestion and digestion processes of three species of heterotrophic nanoflagellate. Microb Ecol 42:168-176

Boenigk J, Matz C, Jürgens K, Arndt H (2001b) Confusing selective feeding with differential digestion in bacterivorous nanoflagellates. J Eukaryot Microbiol 48:425-432

- Boenigk J, Matz C, Jürgens K, Arndt H (2002) Food concentration-dependent regulation of food selectivity of interception-feeding bacterivorous nanoflagellates. Aquat Microb Ecol 27:195-202

> Brooks JL, Dodson SI (1965) Predation, body size and composition of plankton. Science 150:28-35

> Buskey EJ (1997) Behavioral components of feeding selectivity of the heterotrophic dinoflagellate Protoperidinium pellucidum. Mar Ecol Prog Ser 153:77-89

Buskey EJ, Stoecker DK (1988) Locomotory patterns of the planktonic ciliate Favella sp.: adaptations for remaining within food patches. Bull Mar Sci 43:783-796

Buskey EJ, Stoecker DK (1989) Behavioral responses to the marine tintinnid Favella sp. to phytoplankton: influence of chemical, mechanical and photic stimuli. J Exp Mar Biol Ecol 132:1-16

Butler H, Rogerson A (1997) Consumption rates of six species of marine benthic naked amoebae (Gymnoamoeba) from sediments in the Clyde sea area. J Mar Biol Assoc UK 77:989-997

> Caron DA, Gobler CJ, Lonsdale DJ, Cerrato RM and others (2004) Microbial herbivory on the brown tide alga, Aureococcus anophagefferens: results from natural ecosystems, mesocosms and laboratory experiments. Harmful Algae 3:439-457

Christaki U, Dolan JR, Pelegri S, Rassoulzadegan F (1998) Consumption of picoplankton-size particles by marine ciliates: effects of physiological state of the ciliate and particle quality. Limnol Oceanogr 43:458-464

> Christensen-Dalsgaard KK, Fenchel T (2003) Increased filtration efficiency of attached compared to free-swimming flagellates. Aquat Microb Ecol 33:77-86

Chung CY, Funamoto S, Firtel RA (2001) Signaling pathways controlling cell polarity and chemotaxis. Trends Biochem Sci 26:557-566

Cleven EJ (2004) Pelagic ciliates in a large mesotrophic lake: seasonal succession and taxon-specific bacterivory in Lake Constance. Int Rev Gesamten Hydrobiol 89:289-304 
Crawford DW (1992) Metabolic cost of motility in planktonic protists - theoretical considerations on size scaling and swimming speed. Microb Ecol 24:1-10

> Davidson K (1996) Modelling microbial food webs. Mar Ecol Prog Ser 145:279-296

Davidson K, Cunningham A, Flynn KJ (1995a) Predator-prey interactions between Isochrysis galbana and Oxyrrhis marina. III. Mathematical modelling of predation and nutrient regeneration. J Plankton Res 17:465-492

Davidson K, Flynn KJ, Cunningham A (1995b) A first attempt of model factors affecting the ingestion of prey by the dinoflagellate Oxyrrhis marina. Cytology 37:969-977

> Davidson K, Roberts EC, Wilson AM, Mitchell E (2005) The role of prey nutritional status in governing protozoan nitrogen regeneration efficiency. Protist 156:45-62

Davidson K, Gilpin LC, Hart M, Fouillard E and others (2007) The influence of the balance of inorganic and organic nitrogen on microbial food web dynamics. Limnol Oceanogr 52:2147-2163

Davis DP, Fiekers JF, Van Houten JL (1998) Intracellular pH and chemoresponse to $\mathrm{NH}_{4}{ }^{+}$in Paramecium. Cell Motil Cytoskeleton 40:107-118

> DeLaca TE, Bernhard JM, Reilly AA, Bowser SS (2002) Notodendrodes hyalinosphaira (sp. nov.): structure and autoecology of an allogromiid-like agglutinated foraminifer. J Foraminifer Res 32:177-187

Dolan JR, Šimek K (1997) Processing of ingested matter in Strombidium sulcatum, a marine ciliate (Oligotrichida). Limnol Oceanogr 42:393-397

Dolan JR, Šimek K (1999) Diel periodicity in Synechococcus populations and grazing by heterotrophic nanoflagellates: analysis of food vacuole contents. Limnol Oceanogr 41:1169-1179

Dolan JR, Sall N, Metcalfe A, Gasser B (2003) Effects of turbulence on the feeding and growth of a marine oligotrich ciliate. Aquat Microb Ecol 31:183-192

Eccleston-Parry JD, Leadbeater BSC (1994) A comparison of the growth kinetics of six marine heterotrophic nanoflagellates fed with one bacterial species. Mar Ecol Prog Ser 105:167-177

Ehrenberg CG (1838) Die Infusionsthierchen als vollkommene Organismen. Voss, Leipzig

Epstein SS, Shiaris MP (1992) Size selective grazing of coastal bacterioplankton by natural assemblages of pigmented flagellates, colourless flagellates and ciliates. Microb Ecol 23:211-225

Fenchel T (1984) Suspended marine bacteria as a food source. In: Fasham MJ (ed) Flow of material and energy in marine ecosystems. Plenum Press, New York, p 301-315

Fenchel T (1986) Protozoan filter feeding. Prog Protistol 1: 65-113

Fenchel T (1987) The ecology of protozoa. Springer-Verlag, Berlin

Fenchel T (2004) Orientation in two dimensions: chemosensory motile behaviour of Euplotes vannus. Eur J Protistol 40:49-55

Fenchel T, Blackburn N (1999) Motile chemosensory behaviour of phagotrophic protists: mechanisms for and efficiency in congregating at food patches. Protist 150: 325-336

Fenchel T, Jonsson PR (1988) The functional biology of Strombidium sulcatum, a marine oligotrich ciliate (Ciliophora, Oligotrichina). Mar Ecol Prog Ser 48:1-15

Ferrier-Pagès C, Rassoulzadegan F (1994) Seasonal impact of the microzooplankton on pico- and nanoplankton growth rates in the northwest Mediterranean Sea. Mar Ecol Prog Ser 108:283-294

Ferrier-Pagès C, Karner M, Rassoulzadegan F (1998) Release of dissolved amino acids by flagellates and ciliates grazing on bacteria. Oceanol Acta 21:485-494

> Flynn KJ (2006) Reply to Horizons Article ‘Plankton functional type modelling: running before we can walk' Anderson (2005): II. Putting trophic functionality into plankton functional types. J Plankton Res 28:873-875

> Flynn KJ, Davidson K (1993) Predator-prey interactions between Isochrysis galbana and Oxyrrhis marina II. Release of non-protein amines and faeces during predation of Isochrysis. J Plankton Res 15:893-905

Flynn KJ, Davidson K, Cunningham A (1996) Prey selection and rejection by a microflagellate; implications for the study and operation of microbial food webs. J Exp Mar Biol Ecol 196:357-372

Fok AK, Lee Y, Allen RD (1982) The correlation of digestive $\mathrm{pH}$ and size with digestive cycle in Paramecium caudatum. J Protozool 24:502-507

Gilbert JJ (1987) The Polyarthra escape from response: defence against interference from Daphnia. Hydrobiologia 147:235-238

Gonzalez JM, Iriberri J, Egea L, Barcina I (1990) Differential rates of digestion of bacteria by freshwater and marine phagotrophic protozoa. Appl Environ Microbiol 56: 1851-1857

Granéli E, Johansson N (2003) Effects of the toxic haptophyte Prymnesium parvum on the survival and feeding of a ciliate: the influence of different nutrient conditions. Mar Ecol Prog Ser 254:49-56

> Granum E, Kirkvold S, Myklestad SM (2002) Cellular and extracellular production of carbohydrates and amino acids by the marine diatom Skeletonema costatum: diel variations and effects of N depletion. Mar Ecol Prog Ser 242: 83-94

Hahn MW, Höfle MG (2001) Grazing of protozoa and its effect on populations of aquatic bacteria. FEMS Microbiol Ecol 35:113-121

Hansen PJ (1989) The red tide dinoflagellate Alexandrium tamarense: effect on behaviour and growth of a tintinnid ciliate. Mar Ecol Prog Ser 53:105-116

Hansen PJ (1992) Prey size selection, feeding rates and growth dynamics of heterotrophic dinoflagellates with special emphasis on Gyrodinium spirale. Mar Biol 114: 327-334

Hansen PJ, Calado AJ (1999) Phagotrophic mechanisms and prey selection in free-living dinoflagellates. J Eukaryot Microbiol 46:382-383

> Hansen PJ, Nielsen TG (1997) Mixotrophic feeding of Fragilidium subglobosum (Dinophyceae) on three species of Ceratium: effects of prey concentration, prey species and light intensity. Mar Ecol Prog Ser 147:187-196

Hansen B, Hansen PJ, Nielsen TG (1991) Effects of large nongrazable particles on clearance and swimming behaviour of zooplankton. J Exp Mar Biol Ecol 152:257-269

- Hartz AJ, Sherr BF, Sherr EB (2008) Using inhibitors to investigate the involvement of cell signaling in predation by marine phagotrophic protists. J Eukaryot Microbiol 55:18-21

Hausmann K (2002) Food acquisition, food ingestion and food digestion by protists. Jpn J Protozool 35:85-95

> Hessen DO, De Lange HJ, Van Donk E (1997) UV-induced changes in phytoplankton cells and its effects on grazers. Freshw Biol 38:513-524

- Hoffman RL, Atlas RM (1987) Measurement of the effects of cadmium stress on protozoan grazing of bacteria (bacterivory) in activated sludge by fluorescence microscopy. Appl Environ Microbiol 53:2440-2444

> Holen DA, Boraas E (1991) The feeding behavior of Spumella sp. as a function of particle size: implications for bacterial 
size in pelagic systems. Hydrobiologia 220:73-88

Hurlbert SH (1984) Pseudoreplication and the design of ecological field experiments. Ecol Monogr 54:187-211

> Jacobs ME, DeSouza LV, Samaranayake H, Pearlman RE, Siu KW, Klobutcher LA (2006) The Tetrahymena thermophila phagosome proteome. Euk Cell 5:1990-2000

Jacobson DM, Anderson DM (1994) The discovery of mixotrophy in photosynthetic species of Dinophysis (Dinophyceae): light and electron microscopical observations of food vacuoles in Dinophysis acuminata, D. norvegica and two heterotrophic dinophysoid dinoflagellates. Phycologia 33:97-110

> Jacobson DM, Anderson DM (1996) Widespread phagocytosis of ciliates and other protists by mixotrophic and heterotrophic thecate dinoflagellates. J Phycol 32:279-285

Jakobsen HH (2002) Escape of protists in predator-generated feeding currents. Aquat Microb Ecol 26:271-281

> Jakobsen HH, Hansen PJ (1997) Prey size selection, grazing and growth response of the small heterotrophic dinoflagellate Gymnodinium sp. and the ciliate Balanion comatum-a comparative study. Mar Ecol Prog Ser 158:75-86

Jakobsen HH, Tang KW (2002) Effects of protozoan grazing on colony formation in Phaeocystis globosa (Prymnesiophyceae) and the potential costs and benefits. Aquat Microb Ecol 27:261-273

Jakobsen HH, Everett LM, Strom SL (2006) Hydromechanical signaling between the ciliate Mesodinium pulex and motile protist prey. Aquat Microb Ecol 44:197-206

Jennings HS (1906) Behaviour of lower organisms. Columbia University Press, New York, p 41-70

- Jeong HJ, Yoo YD, Seong KA, Kim JH and others (2005) Feeding by the mixotrophic red-tide dinoflagellate Gonyaulax polygramma: mechanisms, prey species, effects of prey concentration, and grazing impact. Aquat Microb Ecol 38:249-257

Jeong HJ, Ha J, Yoo YD, Park JY and others (2007) Feeding by the Pfiesteria-like heterotrophic dinoflagellate Luciella masanensis. J Eukaryot Microbiol 54:231-241

Jezbera J, Horňák K, Šimek K (2005) Food selection by bacterivorous protists: insight from the analysis of the food vacuole content by means of Fluorescence In Situ Hybridization. FEMS Microbiol Ecol 52:351-363

Jezbera J, Horňák K, Šimek K (2006) Prey selectivity of bacterivorous protists in different size fractions of reservoir water amended with nutrients. Environ Microbiol 8:1330-1339

Jin T, Hereld D (2006) Moving toward understanding eukaryotic chemotaxis. Eur J Cell Biol 85:905-913

John EH, Davidson K (2001) Prey selectivity and the influence of prey carbon:nitrogen ratio on microflagellate grazing. J Exp Mar Biol Ecol 260:93-111

Jonsson PR (1986) Particle-size selection, feeding rates and growth dynamics of marine planktonic oligotrichous ciliates (Ciliophora: Oligotrichina). Mar Ecol Prog Ser 33:265-277

Jürgens K, DeMott WR (1995) Behavioral flexibility in prey selection by bacterivorous nanoflagellates. Limnol Oceanogr 40:1503-1507

Jürgens K, Massana R (2008) Protistan grazing on marine bacterioplankton. In: Kirchman DL (ed) Microbial ecology of the oceans, 2nd edn. Wiley-Liss, New York, p 383-441

> Jürgens K, Matz C (2002) Predation as a shaping force for the phenotypic and genotypic composition of planktonic bacteria. Ant Leeuwenhoek 81:413-434

Kamiyama T (1997) Growth and grazing responses of tintinnid ciliates feeding on the toxic dinoflagellate Heterocapsa circularisquama. Mar Biol 128:509-515
Kiefer DA, Berwald J (1992) A random encounter model for the microbial planktonic community. Limnol Oceanogr 37:457-467

- Kim S (2006) Patterns in host range for two strains of Amoebophrya (Dinophyta) infecting thecate dinoflagellates: Amoebophrya spp. ex Alexandrium affine and ex Gonyaulax polygramma. J Phycol 42:1170-1173

Kiørboe T, Titelman J (1998) Feeding, prey selection and prey encounter mechanisms in the heterotrophic dinoflagellate Noctiluca scintillans. J Plankton Res 20:1615-1636

> Kiørboe T, Saiz E, Viitasalo M (1996) Prey switching behaviour in the planktonic copepod Acartia tonsa. Mar Ecol Prog Ser 143:65-75

> Kiørboe T, Grossart HP, Ploug H, Tang KW, Auer B (2004) Particle-associated flagellates: swimming patterns, colonization rates, and grazing on attached bacteria. Aquat Microb Ecol 35:141-152

Kirk KL, Gilbert JJ (1988) Escape behavior of Polyarthra in response to artificial flow stimuli. Bull Mar Sci 43:551-560

- Kopp M, Tollrian R (2003a) Trophic size polyphenism in Lembadion bullinum: costs and benefits of an inducible offense. Ecology 84:641-651

Kopp M, Tollrian R (2003b) Reciprocal phenotypic plasticity in a predator-prey system: inducible offences against inducible defences? Ecol Lett 6:742-748

Kremp A, Anderson DM (2004) Lectin binding patterns of Scrippsiella lachrymosa (Dinophyceae) in relation to cyst formation and nutrient conditions. J Exp Mar Biol Ecol 307:165-181

Kuhlmann HW, Kusch J, Heckmann K (1999) Predator-induced defenses in ciliated protozoa. In: Tollrian R, Harvell C (eds) The ecology and evolution of inducible defenses. Princeton University Press, Princeton, NJ, p 142-159

Landry MR (1994) Methods and controls for measuring the grazing impact of planktonic protists. Mar Microb Food Webs 8:37-57

Landry MR, Hassett RP (1982) Estimating the grazing impact of marine micro-zooplankton. Mar Biol 67:283-288

> Laureillard J, Méjanelle L, Sibuet M (2004) Use of lipids to study the trophic ecology of deep-sea xenophyophores. Mar Ecol Prog Ser 270:129-140

Legrand C, Granéli E, Carlsson P (1998) Induced phagotrophy in the photosynthetic dinoflagellate Heterocapsa triquetra. Aquat Microb Ecol 15:65-75

Leick V, Lindemose S (2007) Chemokinesis by Tetrahymena in response to bacterial oligopeptides. J Eukaryot Microbiol 54:271-274

> Leick V, Koppelhus U, Rosenberg J (1994) Cilia-mediated oriented chemokinesis in Tetrahymena thermophila. J Eukaryot Microbiol 41:546-553

Long JD, Smalley GW, Barsby T, Anderson JT, Hay ME (2007) Chemical cues induce consumer-specific defenses in a bloom-forming marine phytoplankton. Proc Natl Acad Sci USA 104:10512-10517

- Martel CM (2006) Prey location, recognition, and ingestion by the phagotrophic marine dinoflagellate Oxyrrhis marina. J Exp Mar Biol Ecol 335:210-220

Matsuoka A (2007) Living radiolarian feeding mechanisms: new light on past marine ecosystems. Swiss J Geosci 100:273-279

> Matz C, Jürgens K (2001) Effects of hydrophobic and electrostatic cell surface properties of bacteria on feeding rates of heterotrophic nanoflagellates. Appl Environ Microbiol 67: $814-820$

Matz C, Jürgens K (2005) High motility reduces grazing mortality of planktonic bacteria. Appl Environ Microbiol 71:921-929 
Matz C, Boenigk J, Arndt H, Jürgens K (2002) Role of bacterial phenotypic traits in selective feeding of the heterotrophic nanoflagellate Spumella sp. Aquat Microb Ecol 27:137-148

Matz C, Deines P, Boenigk J, Arndt H, Eberl L, Kjelleberg S, Jürgens K (2004) Impact of violacein-producing bacteria on survival and feeding of bacterivorous nanoflagellates. Appl Environ Microbiol 70:1593-1599

Menden-Deuer S, Grunbaum D (2006) Individual foraging behaviors and population distributions of a planktonic predator aggregating to phytoplankton thin layers. Limnol Oceanogr 51:109-116

Mitra A, Flynn KJ (2005) Predator-prey interactions: is 'ecological stoichiometry' sufficient when good food goes bad? J Plankton Res 27:393-399

> Mitra A, Davidson K, Flynn KJ (2003) The influence of changes in predation rates on marine microbial predator/ prey interaction: a modelling study. Acta Oecol 24: S359-S367

Monger BC, Landry MR, Brown SL (1999) Feeding selection of heterotrophic marine nanoflagellates based on the surface hydrophobicity of their picoplankton prey. Limnol Oceanogr 44:1917-1927

Montagnes DJS, Berges JA (2004) Determining parameters of the numerical response. Microb Ecol 48:139-144

Montagnes DJS, Lessard EJ (1999) Population dynamics of the marine planktonic ciliate Strombidinopsis multiauris: its potential to control phytoplankton blooms. Aquat Microb Ecol 20:167-181

Morelli A, Verni N (1996) Predator-prey interactions: effects of the substances released by the prey Euplotes crassus (Protozoa, Ciliata) on the predator Litonotus lamella (Protozoa, Ciliata). Microbios 87:185-198

Murray JW (1991) Ecology and distribution of planktonic foraminifera. In: Lee JJ, Anderson OR (eds) Biology of foraminifera. Academic Press, London, p 255-284

Nanny DL (1980) Experimental ciliophorology: an introduction to genetic and developmental analysis in ciliates. John Wiley \& Sons, New York

Nomaki HN, Heinz P, Nakatsuka T, Shimanaga M and others (2006) Different ingestion patterns of ${ }^{13} \mathrm{C}$-labeled bacteria and algae by deep-sea benthic foraminifera. Mar Ecol Prog Ser 310:95-108

Ochs CA, Eddy LP (1998) Effects of UV-A (320 to $399 \mathrm{~nm}$ ) on grazing pressure of a marine heterotrophic nanoflagellate on strains of the unicellular cyanobacteria Synechococcus spp. Appl Environ Microbiol 64:287-293

Okada M, Huston CD, Mann BJ, Petri WA, Kita K, Nozaki T (2005) Proteomic analysis of phagocytosis in the enteric protozoan parasite Entamoeba histolytica. Eukaryot Cell 4:827-831

Paffenhöfer GA, Sherr BF, Sherr EB (2007) From small scales to the big picture: persistence mechanisms of planktonic grazers in the oligotrophic ocean. Mar Ecol Evol Persp 28:243-253

Page FC (1988) A new key to freshwater and soil Gymnamoebae, with instructions for culture. Freshwater Biological Association, Ambleside

Pajdak-Stós A, Fialkowska E, Fyda J (2001) Phormidium autumnale (Cyanobacteria) defense against three ciliate grazer species. Aquat Microb Ecol 23:237-244

Parent CA, Devreotes PN (1999) A cell's sense of direction. Science 284:765-770

Park MG, Kim S, Kim HS, Myung G, Kang YG, Yih W (2006) First successful culture of the marine dinoflagellate Dinophysis acuminata. Aquat Microb Ecol 45:101-106

Parry JD (2004) Protozoan grazing of freshwater biofilms.
Adv Appl Microbiol 54:167-196

Pernthaler J (2005) Predation on prokaryotes in the water column and its ecological implications. Nat Rev Microbiol 3:537-546

- Peters F, Choi JW, Gross T (1996) Paraphysomonas imperforata (Protista, Chrysomonadida) under different turbulence levels: feeding, physiology and energetics. Mar Ecol Prog Ser 134:235-245

Pettitt ME, Orme BAA, Blake JR, Leadbeater BSC (2002) The hydrodynamics of filter feeding choanoflagellates. Eur J Protistol 38:313-332

Pfandl K (2003) Characterization of size selectivity by filter and interception feeding protists (Cyclidium glaucoma, Ochromonas sp., Spumella sp.) using epifluorescence- and video microscopy. Diploma thesis, University of Innsbruck

Pfandl K, Posch T, Boenigk J (2004) Unexpected effects of prey dimensions and morphologies on the size selective feeding by two bacterivorous flagellates (Ochromonas sp. and Spumella sp.). J Eukaryot Microbiol 51:626-633

Pfister G, Arndt H (1998) Food selectivity and feeding behaviour in omnivorous filter-feeding ciliates: a case study for Stylonychia. Eur J Protistol 34:446-457

> Pickup ZL, Pickup R, Parry JD (2007) Growth of Acanthamoeba castellanii and Hartmannella vermiformis on live, heat-killed and DTAF-stained bacterial prey. FEMS Microbiol Ecol 61:264-272

> Pohnert G, Steinke M, Tollrian R (2007) Chemical cues, defence metabolites and the shaping of pelagic interspecific interactions. Trends Ecol Evol 22:198-204

Rassoulzadegan F (1982) Feeding in marine planktonic protozoa. Ann Inst Oceanogr Paris (Nouv Ser) 58:191-205 (Suppl S)

Rezabek BL, Rodriguez-Paris JM, Cardelli JA, Chia CP (1997) Phagosomal proteins of Dictyostelium discoideum. J Eukaryot Microbiol 44:284-292

Roa R (1992) Design and analysis of multiple-choice feedingpreference experiments. Oecologia 89:509-515

Ronn R, McCraig AE, Griffiths BS, Prosser JI (2002) Impact of protozoan grazing on bacterial community structure in soil microcosms. Appl Environ Microbiol 68:6094-6105

Sakaguchi M, Murakami H, Suzaki T (2001) Involvement of a 40-kDa glycoprotein in food recognition, prey capture, and induction of phagocytosis in the protozoan Actinophrys sol. Protist 152:33-41

Sanders RW (1988) Feeding by Cyclidium sp. (Ciliophora, Scuticociliatida) on particles of different sizes and surfaceproperties. Bull Mar Sci 43:446-457

Seravin LN, Orlovskaja EE (1977) Feeding-behavior of unicellular animals. 1. Main role of chemoreception in food choice of carnivorous protozoa. Acta Protozool 16:309-332

Shannon SP, Chrzanowski TH, Grover JP (2007) Prey food quality affects flagellate ingestion rates. Microb Ecol 53:66-73

Sherr BF, Sherr EB, Fallon RD (1987) Use of monodispersed, fluorescently labeled bacteria to estimate in situ protozoan bacterivory. Appl Environ Microbiol 53:958-965

Sherr BF, Sherr EB, Rassoulzadegan F (1988) Rates of digestion of bacteria by marine phagotrophic protozoa: temperature dependence. Appl Environ Microbiol 54:1091-1095

Sherr EB, Sherr BF (1993) Protistan grazing rates via uptake of fluorescently labeled prey. In: Kemp P, Sherr BF, Sherr EB, Cole J (eds) Handbook of methods in aquatic microbial ecology. Lewis Publishers, Boca Raton, FL, p 695-701

Sherr EB, Sherr BF (1997) Phagotrophy in aquatic microbial food webs. In: Hurst CJ, Knudsen GR, McInerney MJ, Stetzenbach LD, Walter MV (eds) Manual of environmental microbiology. ASM Press, Washington, DC, p 309-316 
Sherr EB, Sherr BF (2002) Significance of predation by protists in aquatic microbial food webs. Ant Leeuwenhoek 81:293-308

Shimeta J, Jumars PA, Lessard EJ (1995) Influences of turbulence on suspension feeding by planktonic protozoa: experiments in laminar shear fields. Limnol Oceanogr 40:845-859

Sibbald MJ, Albright LJ, Sibbald PR (1987) Chemosensory responses of a heterotrophic microflagellate to bacteria and several nitrogen compounds. Mar Ecol Prog Ser 36:201-204

Šimek K, Chrzanowski TH (1992) Direct and indirect evidence of the size selective grazing on pelagic bacteria by freshwater nanoflagellates. Appl Environ Microbiol 58: 3715-3720

Šimek K, Jürgens K, Nedoma J, Comerma M, Armengol J (2000) Ecological role and bacterial grazing of Halteria spp.: small freshwater oligotrichs as dominant pelagic ciliate bacterivores. Aquat Microb Ecol 22:43-56

Šimek K, Horňák K, Jezbera J, Nedoma J and others (2006) Maximum growth rates and possible life strategies of different bacterioplankton groups in relation to phosphorus availability in a freshwater reservoir. Environ Microbiol 8:1613-1624

Šimek K, Weinbauer MG, Horňák K, Jezbera J, Nedoma J, Dolan JR (2007) Grazer and virus-induced mortality of bacterioplankton accelerates development of Flectobacillus populations in a freshwater community. Environ Microbiol 9:789-800

Skovgaard A (1996) Engulfment of Ceratium spp. (Dinophyceae) by the thecate photosynthetic dinoflagellate Fragilidium subglobosum. Phycologia 35:490-499

Smalley GW, Coats DW, Adam EJ (1999) A new method using fluorescent microspheres to determine grazing on ciliates by the mixotrophic dinoflagellate Ceratium furca. Aquat Microb Ecol 17:167-179

Stelfox-Widdicombe CE, Edwards ES, Burkill PH, Sleigh MA (2000) Microzooplankton grazing activity in the temperate and sub-tropical NE Atlantic: summer 1996. Mar Ecol Prog Ser 208:1-12

Stoecker DK (1998) Conceptual models of mixotrophy in planktonic protists and some ecological and evolutionary implications. Eur J Protistol 34:281-290

Stoecker DK, Guillard RRL (1982) Effects of temperature and light on the feeding rate of Favella sp. (Ciliated Protozoa, Suborder Tintinnina). Ann Inst Océanogr Paris 58(S):309-318

Stoecker DK, Gallager SM, Langdon CJ, Davis LH (1995) Particle capture by Favella sp. (Ciliata, Tintinnina). J Plankton Res 17:1105-1124

Stolte W, Lindstrom T, Granéli E (2007) Enhancement of poorly edible phytoplankton by allochthonous dissolved organic material: a modelling study. Aquat Microb Ecol 46:263-272

Strom SL (2001) Light-aided digestion, grazing and growth in herbivorous protists. Aquat Microb Ecol 23:253-261

Strom SL, Buskey EJ (1993) Feeding, growth, and behaviour of the thecate heterotrophic dinoflagellate Oblea rotunda. Limnol Oceanogr 38:965-977

Strom SL, Loukos H (1998) Selective feeding by protozoa: model and experimental behaviors and their consequences for population stability. J Plankton Res 20: 831-846

Strom S, Wolfe G, Slajer A, Lambert S, Clough J (2003) Chemical defense in the microplankton. II: Inhibition of protist feeding by beta-dimethylsulfoniopropionate (DMSP). Limnol Oceanogr 48:230-237

> Strom SL, Wolfe GV, Bright KJ (2007) Responses of marine planktonic protists to amino acids: feeding inhibition and swimming behavior in the ciliate Favella sp. Aquat Microb Ecol 47:107-121

Suhr SB, Pond DW, Gooday AJ, Smith CR (2003) Selective feeding by benthic foraminifera on phytodetritus on the western Antarctic Peninsula shelf: evidence from fatty acid biomarker analysis. Mar Ecol Prog Ser 262:153-162

Taniguchi A, Takeada Y (1988) Feeding rate and behavior of the tintinnid ciliate Favella taraikaensis observed with a high speed VTR system. Mar Microb Food Webs 3:21-34

Taylor WB, Berger J (1980) Micro-spatial heterogeneity in the distribution of ciliates in a small pond. Microb Ecol 6:27-34

Tillmann U (2003) Kill and eat your predator: a winning strategy of the planktonic flagellate Prymnesium parvum. Aquat Microb Ecol 32:73-84

Tillmann U (2004) Interactions between planktonic microalgae and protozoan grazers. J Eukaryot Microbiol 51: 156-168

Tobiesen A (1990) Temperature dependent filtration rates and size selection in some heterotrophic microflagellates and one dinoflagellate. Arch Hydrobiol Beih Ergebn Limnol 34:293-304

Ucko M, Geresh S, Simon-Berkovitch B, Arad (Malis) S (1994) Predation by a dinoflagellate on a red microalga with a cell wall modified by sulphate and nitrate starvation. Mar Ecol Prog Ser 104:293-298

Van Houten JL, Yang WQ, Bergeron A (2000) Chemosensory signal transduction in Paramecium. J Nutr 130:946S-949S

- Vaulot D, Romari K, Not F (2002) Are autotrophs less diverse than heterotrophs in marine picoplankton? Trends Microbiol 10:266-267

Vázquez-Domínguez E, Casamayor EO, Català P, Lebaron P (2005) Different marine heterotrophic nanoflagellates affect differentially the composition of enriched bacterial communities. Microb Ecol 49:474-485

> Venkataraman C, Haack BJ, Bondada S, AbuKwaik Y (1997) Identification of a Gal/GalNAc lectin in the protozoan Hartmannella vermiformis as a potential receptor for attachment and invasion by the Legionnaires' disease bacterium. J Exp Med 186:537-547

Verity PG (1991) Measurement and simulation of prey uptake by marine planktonic ciliates fed plastidic and aplastidic nanoplankton. Limnol Oceanogr 36:729-750

Weekers PHH, Bodelier PLE, Wijen JPH, Vogels GD (1993) Effects of grazing by the free-living soil amoebae Acanthamoeba castellanii, Acanthamoeba polyphaga, and Hartmannella vermiformis on various bacteria. Appl Environ Microbiol 59:2317-2319

Weisse $\mathrm{T}$ (1997) Growth and production of heterotrophic nanoflagellates in a meso-eutrophic lake. J Plankton Res 19:703-722

Wicklow BJ (1997) Signal-induced defensive phenotype changes in ciliates protists: morphological and ecological implications for predator and prey. J Eukaryot Microbiol 44:176-188

Wildschutte H, Wolfe DM, Tamewitz A, Lawrence JG (2004) Protozoan predation, diversifying selection, and the evolution of antigenic diversity in Salmonella. Proc Natl Acad Sci USA 101:10644-10649

Wolfe GV, Steinke M, Kirst GO (1997) Grazing-activated chemical response in a unicellular marine alga. Nature 387:894-897

> Wootton EC, Zubkov MV, Jones DH, Martel CM, Thornton CA, Roberts EC (2007) Biochemical prey recognition by planktonic protozoa. Environ Microbiol 9:216-222

> Wu QL, Boenigk J, Hahn MW (2004) Successful predation of filamentous bacteria by a nanoflagellate challenges current models of flagellate bacterivory. Appl Environ Microbiol 70:332-339 